\title{
REVIEW
}

\section{Novel modalities of somatostatin actions}

\author{
S Krantic, I Goddard, A Saveanu, N Giannetti ${ }^{1}$, J Fombonne, A Cardoso, P Jaquet and A Enjalbert \\ Interactions Cellulaires Neuroendocriniennes (ICNE), Unité Mixte de Recherche (UMR 6544), Centre National de Recherche Scientifique \\ (CNRS)/Université de la Méditerranée, Institut Jean Roche, Faculté de Médecine Nord, 13916, Marseille, France and ${ }^{1}$ Laboratoire de Neurosciences, \\ Institut Fédératif de Recherche Franche-Comté, F-25030 Besançon, France
}

(Correspondence should be addressed to S Krantic; Email: krantic@inmed.univ-mrs.fr)

\begin{abstract}
The first part of this contribution reviews the current knowledge about endocrine and neuromodulatory actions of somatostatin. These biological actions are exerted according to endocrine, paracrine and autocrine modes of action and involve five distinct types of membrane receptors belonging to the 'super-family' of G-protein-coupled receptors.

A new concept concerning a juxtacrine mode of action has recently been introduced to refer to the intervention of cytokines and growth factors in direct, cell-to-cell communication. The evidence in favor of juxtacrine actions of somatostatin will be presented in the second part of this review and illustrated by our own results on macrophage-lymphocyte $\mathrm{T}$ interactions in the immune system and spermatogonia-Sertoli cell interactions in mammalian testis. Another phenomenon such as ligand-induced somatostatin receptor homo- and hetero-dimerization resulting in 'poly'-receptors (with characteristics different from those of each of the two receptors forming the complex) is also at the origin of a novel mode of somatostatin action. The latter will be illustrated by the data obtained on human pituitary adenomas with somatostatin analogs specific for either 'poly'-receptor or relevant individual receptors.

The arguments in favor of the analogous mode of actions among different families of chemical messengers such as peptides, cytokines and growth factors are discussed in the concluding section. The emerging unifying concepts on such functional analogies might provide a useful basis for the development of synthetic analogs not only for bioactive peptides but also for other types of chemical messengers.
\end{abstract}

European Journal of Endocrinology $151643-655$

\section{Introduction}

Bioactive peptides, cytokines and growth factors represent the major types of chemical messengers. Classically, bioactive peptides designate peptidic hormones and neuromediators. Cytokines are mediators of the cell communication in the immune system whereas growth factors represent signals controlling cell division and/or differentiation notably during embryonic induction. Distinction between these three families of polypeptides/glycoproteins is more historical and didactic than functional. Indeed, there is often no clear distinction between the three families and, moreover, the same peptide might functionally belong to all three families.

In addition, natural peptides, cytokines and growth factors have pleiotropic effects and can be released by a multitude of cell types. (For this reason the term 'lymphokines' referring to their lymphocyte origin has been changed to cytokine.) Growth factors and cytokines display 'context'-dependent actions (i.e. their function depends on the presence of other cytokines and/or their regulators such as binding proteins, soluble receptors or antagonists). They exert specific actions locally in an autocrine, paracrine or juxtacrine manner. In contrast, hormonal polypeptides are secreted into the circulation and transported to the target organs that are located at a distance from their production site. However, it is now well recognized that bioactive peptides also exert autocrine and paracrine actions.

Concerning the relevant receptors, there are slight differences in the way the ligand triggers the initial receptor activation upon binding but the final cellular response is elaborated according to a common, general principle consisting (among other pathways) in activation of different types of protein kinases. For example, cytokine receptors are made by association of a different number of polypeptide chains; most of them have no intrinsic kinase activity and, in this case, signal transduction involves the association of these receptors with cytoplasmic tyrosine kinases. Growth factor receptors are single polypeptide chains with an intrinsic 
tyrosine kinase activity. However, the induction of tyrosine kinase activity requires ligand-induced receptor dimerization. In the case of bioactive peptides, receptors are made of a single polypeptide chain spanning the plasma membrane in seven transmembrane domains and are coupled to G-proteins (G-protein-coupled receptors or GPCRs). In resting conditions, G-proteins exist as heterotrimers with GDP bound to their $\alpha$-subunits. Ligand binding to GPCR triggers a conformational change of GPCR and subsequent activation of a specific G-protein leading to GDP/GTP exchange on G-protein and dissociation of its $\alpha$-subunit from $\beta / \gamma$-subunits. GTP is hydrolyzed to GDP due to the intrinsic GTPase activity of G-protein thus terminating the cycle of G-protein activation. Dissociated G-protein subunits (i.e. both $\alpha$ and $\beta / \gamma$ ) activate different transmembrane effectors (e.g. adenylyl cyclases, phospholipases). The effector activation subsequent to ligand-receptor interaction results in a second messenger production and activation of the relevant protein kinases. In all cases, protein kinase-driven phosphorylation results in functional alteration of down-stream effectors (ion channels, enzymes, transcription factors) and an adequate cellular response.

\section{Somatostatin peptide family}

The somatostatin (somatotroph release inhibiting factor, SRIF) neuropeptide family comprises few peptides originating from different posttranslational processing of the prepro-SRIF precursor of 116 amino acids. The precursor is encoded by a single gene located in humans on chromosome 3q28. Only two biologically active SRIF isoforms have been identified so far: the tetradecapeptide SRIF-14 and the amino-terminally extended octacosapeptide SRIF-28 (the entire somatostatin-14 sequence is present in the C-terminus of somatostatin-28). Both SRIF-14 and SRIF-28 are found in the periphery and central nervous system (CNS) but the predominant isoform is SRIF-14. The relative proportions of the two isoforms differ among various SRIF-producing tissues. However, SRIF-14 and SRIF-28 display overlapping physiological functions.

The classical physiological functions of SRIF include the inhibition of a wide range of endocrine secretions. Thus, SRIF inhibits the secretions of the pituitary (growth hormone, prolactin and thyrotropin), gastrointestinal tract (cholecystokinin, gastric inhibitory peptide, gastrin, motilin, neurotensin and secretin) and pancreas (glucagon, insulin and pancreatic polypeptide). In the CNS, SRIF acts as a neurotransmitter by itself in distinct, anatomically defined pathways and as a neuromodulator since it has the capacity to modulate the release of other neurotransmitters (among which are serotonin, acetylcholine, glutamate) and neurohormones (e.g. growth hormone-releasing hormone).
Inhibition of various exocrine functions by SRIF is well documented for the secretion of amylase (by salivary glands), hydrochloric acid and pepsinogen (by gastrointestinal mucosa), pancreatic enzymes and bicarbonate (by pancreatic acini) and bile (by liver). SRIF also regulates the intestinal absorption of nutrients and gastro-intestinal motility in a complex manner.

In addition, SRIF has potent immunomodulatory actions on the secretion activity of immune cells such as immunoglobulin (Ig) production by activated B-lymphocytes and cytokine production by activated T-lymphocytes and macrophages. For example, SRIF decreases production of $\operatorname{IgA}$, IgM and IgE by B-lymphocytes and modulates interleukin (IL)-2, IL-4, IL-10 and interferon- $\gamma$ secretion by T-lymphocytes. Furthermore, somatostatin is apparently involved in the regulation of the Th1/Th2 pattern of cytokine secretion by murine T-cell lines. SRIF also inhibits the secretory responses of some other types of immune cells such as IgE-stimulated histamine and inflammatory cytokines (tumor necrosis factor- $\alpha$, IL- $1 \beta$ and IL- 6 ) released from basophils and monocytes respectively. SRIF is also involved in inhibition of neutrophil's chemotaxis, phagocytic activity of monocytes/macrophages and natural killer cell activity.

The proliferative response to antigens/mitogens of different types of immune cells is modulated by SRIF in a complex manner. Indeed, the observed actions on B- and T-lymphocyte proliferation are multimodal: both inhibitory and stimulatory effects have been reported depending on the SRIF concentration, the way in which the immune cell activation was achieved and on the cell phenotype (normal versus malignant) (for review, see 1).

Another peptide, which does not belong strictu senso to the SRIF peptide family but shares 11 amino acids with SRIF, has recently been characterized and named cortistatin (CST). The biologically active form of CST is the tetradecapeptide (CST-14) in rodents and the heptadecapeptide (CST-17) in humans, corresponding to rodent CST-14 amino-terminally extended by 3 amino acids. The CST gene maps to chromosome 4 and 1p36 in rodents and humans respectively. In contrast to SRIF, CST appears predominantly to be confined to the CNS and in particular to the inhibitory inter-neurons of the cerebral cortex and hippocampus. The biological actions of CST involve the regulation of sleep-phase transitions, consolidation of short- and long-term memory and locomotor activity (2). Among human peripheral tissues studied, the highest CST expression has been reported in kidney and testes (3) but CST has also been found in pancreas (4) and in hepatocellular carcinoma cells (5). In the immune system, CST is expressed in human T- and B-lymphocytes (6) as well as in monocytes and monocyte-derived cells such as macrophages and dendritic cells (7). It is currently believed that CST exerts at least some of its biological effects by acting as 
an endogenous ligand on SRIF receptors (for review, see $8)$. This has, in particular, been suggested for the cells of the human immune system (9). However, it has recently been discovered that the orphan MrgX2 receptor binds CST in a highly specific and efficient manner (10), thus suggesting that CST exerts its effects not only by interacting with SRIF receptors but also through its own receptors.

\section{Somatostatin (sst) receptor family}

Molecular characterization of rodent and human SRIF receptors indicated that five different receptors underlie the biological actions of the peptide. They are encoded by five different genes and are highly conserved between species (e.g. sst1 of mouse and human share $99 \%$ of the amino acid sequence) and within the same species (different SRIF receptors present 45$67 \%$ identity between each other). Human genes encoding the sst1, sst2, sst3, sst4 and sst5 receptors have been mapped to $14 \mathrm{q} 13,17 \mathrm{q} 24,22 \mathrm{q} 13.1$, $20 \mathrm{p} 11.2$ and $16 \mathrm{p} 13.3$ respectively. Their expression products correspond to monomers composed of 391 (sst1), 369 (sst2), 418 (sst3), 388 (sst4) and 383 (sst5) amino acids. Among these receptors, sst2 appears unique since, in mouse, it can be differentially spliced upon transcription giving rise to two splice variants of 369 (sst2A) and 346 (sst2B) amino acids.

All five somatostatin receptors have been identified throughout the CNS, endocrine and exocrine glands (Table 1). The expression of mRNA for the five cloned receptors is overlapping but the combination (profile) of expression is tissue- and cell type-specific. In more detail, rodent CNS mRNAs for all five types of SRIF receptors have been seen in the cerebral cortex, striatum, hippocampus, amygdala, olfactory bulb and preoptic area (mouse (11); rat (12)). Among different types of receptors, sst 1 and sst 2 are the most abundantly expressed whereas the expression of sst3, sst4 and sst5 appears less important. Transcripts for all five receptor types have been visualized in rat but not in human pituitaries where sst4 mRNA is not expressed. Rat and human pancreas, stomach, duodenum, jejunum and ileum contain the transcripts for sst1-sst5 receptors. Other peripheral organs and tissues express SRIF receptor transcripts more selectively. For example, rat adrenals and testes contain sst1sst3 transcripts. Elevated expressions of sst3 in liver and spleen and of sst 4 in lung, heart and placenta have been seen. The expression of sst $2 \mathrm{~A}$ and sst 3 receptor mRNAs has been reported in cells of the immune system such as activated macrophages, and T- and Blymphocytes (for reviews see 1, 13, 14).

Both biologically active forms of SRIF (SRIF-14 and SRIF-28) recognize the five cloned receptors with similar affinities, but somatostatin-28 binds to sst5 receptors with slightly (tenfold) better affinity. Two subfamilies of somatostatin receptors are distinguished based on their affinity for routinely used analogs. Thus, octreotide (SMS 201-995), vapreotide (RC 160) and lanreotide (BIM 23014) distinguish sst2 > sst3/sst5 from sst $1 /$ sst 4 since they bind to the sst $2 /$ sst $3 /$ sst 5 subfamily with high-to-moderate affinity and binding is 1000 -fold less efficient to the sst1/sst4 subfamily of receptors. However, more recently a series of receptor subtype-selective analogs has become available (Table 1). In addition, a new agonist (SOM230) with high affinity for sst1, sst2, sst3 and sst5 and with a lower affinity for sst4 has also been synthesized. SOM230 thus appears as a 'universal' ligand for all types of SRIF receptors (15) which, in this context, is similar to the natural peptide.

All five cloned somatostatin receptors (sst1-sst5) belong to the superfamily of G-protein-coupled receptors with seven transmembrane domains. The activation of G-proteins upon somatostatin binding is, however, coupled to multiple signaling pathways (Table 1). After expression of the cloned receptors in heterologous cell lines, all of them (sst1-sst5) inhibit the adenylyl cyclase activity (through G $\alpha 1-3$ ) but, in parallel, also selectively activate other transduction effectors such as phospholipase-C $\beta$ (through both pertussis toxin-dependent and -independent G-proteins). In addition, SRIF receptors activate several types of ionic channels (inward rectifying $\mathrm{K}^{+}$-channels and high voltage dependent $\mathrm{Ca}^{+}$-channels). A number of phosphatases such as serine/threonine phosphatases, tyrosine phosphatases and $\mathrm{Ca}^{+}$-dependent phosphatases are also involved in transduction of SRIF actions. Effectors such as extracellular regulated kinase (ERK) $1 / 2$ and $\mathrm{Na}^{+} / \mathrm{H}^{+}$-exchanger also mediate SRIF-induced cellular responses $(13,16,17)$.

The question concerning the selective involvement of different somatostatin receptors in specific physiological responses to SRIF is still a matter of debate. However, some precise physiological functions could be attributed to each of the five known receptors. The majority of the relevant data came from the studies on knock-out (KO) mice in which gene encoding for a given somatostatin receptor has been invalidated. These animals are now available for each of the five receptors (e.g. for sst1sst4 (18) and for sst5 (19)) but the most studied remain sst 2 and sst5 KO mice. The studies of sst2 gene KO mice indicated that this receptor displays specific central actions such as fine motor control (20), modulation of spatial learning (21), exploratory activity and emotional reactivity (22). Among the peripheral actions of SRIF, sst2 receptor appears specifically involved in the inhibition of gastric acid secretion $(23,24)$. Analysis of the sst5 KO phenotype showed that this receptor mediates SRIF-induced inhibition of insulin secretion and glucose homeostasis (19) in an age-dependent manner (25).

Certain physiological roles of somatostatin receptors that had initially been suggested based on their colocalization with hormones have therefore been 
Table 1 Characteristics of somatostatin receptors.

\begin{tabular}{|c|c|c|c|c|c|c|c|c|c|c|}
\hline & sst1 & Reference & sst2 & Reference & sst3 & Reference & sst 4 & Reference & sst5 & Reference \\
\hline \multirow[t]{2}{*}{ Ligand selectivity } & L-797591 & 76 & L-054522 & 69,76 & $\begin{array}{l}\text { L-796778 } \\
\text { BN-81644 }\end{array}$ & 76,79 & $\begin{array}{l}\text { L-803087 } \\
\text { NNC-269100 }\end{array}$ & 76,80 & BIM-23268 & 74 \\
\hline & & & L-779976 & 77,78 & BN-81674 & & & & & \\
\hline \multicolumn{11}{|l|}{ Signal transduction } \\
\hline Adenylyl cyclase & - & 81,82 & - & $83,84,78$ & - & $85,86,87$ & - & 88,89 & - & 90,91 \\
\hline Ca-channels & - & 92 & \pm & $93,94,95,96$ & & & & & - & 95 \\
\hline K-channels & - & 97 & + & 98 & + & 98 & + & 98 & + & 98 \\
\hline Phospholipase C & + & 82,99 & + & $99,100,101$ & + & 99,102 & + & 99,103 & \pm & 99,103 \\
\hline MAP kinase & + & 104 & - & 77,105 & - & 106 & + & 88,107 & - & 38 \\
\hline Tyrosine phosphatase & + & 35,108 & + & $35,36,77,109$ & + & 110 & + & 110 & + & 111 \\
\hline Na-proton antiporter & - & 112,113 & \pm & 113 & & & + & 114 & & \\
\hline \multicolumn{11}{|l|}{ Expression - central } \\
\hline Forebrain & + & 115 & + & 115 & + & 85,115 & + & 115,116 & + & 117 \\
\hline Hypothalamus & + & 8,115 & + & 8,115 & + & 8,115 & + & 8,115 & + & 8,90 \\
\hline Cerebellum & & & + & 115 & + & 115 & + & 115 & + & 115,118 \\
\hline \multicolumn{11}{|l|}{ Expression - peripheral } \\
\hline Lung & + & 116 & & & & & + & 116 & & \\
\hline Heart & & & & & & & & & + & 118 \\
\hline Skeletal muscle & & & & & & & & & + & 118 \\
\hline Stomach & + & 119,120 & + & 119,121 & + & 119 & + & 119 & + & 119 \\
\hline Kidney & + & 116 & + & 120,122 & & & & & & \\
\hline Liver & + & 116 & & & & & & & & \\
\hline $\begin{array}{l}\text { Pancreas } \\
\text { Adrenal }\end{array}$ & + & 63,116 & + & 63 & + & $63,85,116$ & + & 63 & $\begin{array}{l}+ \\
+\end{array}$ & $\begin{array}{l}63 \\
118\end{array}$ \\
\hline
\end{tabular}


confirmed by analysis of the relevant receptor $\mathrm{KO}$ phenotype. This is the case for the explicit demonstration coming from $\mathrm{KO}$ mice concerning sst 5 receptor involvement in the regulation of insulin secretion seen also in the histochemical studies by Mitra et al. (26) and Ludvigsen et al. (27). In other cases, as for example concerning the specific roles of the sst1 receptor in the retina, the KO model was less informative. Indeed, it has been reported that the genetic deletion of sst 1 receptor triggers an over-expression of sst 2 receptors and vice-versa (28). This phenomenon of the co-regulation of sst receptor expression particularly hampered the analysis of data obtained in $\mathrm{KO}$ models in relation to the involvement of a given receptor type in the physiological effect of SRIF known to implicate multiple receptors. For example, the involvement of sst1 receptor in the regulation of growth hormone $(\mathrm{GH})$ secretion that has been documented in sst1-null mice (29) should now be reconsidered in the light of the co-regulation of sst1 and sst2 receptor expression (28), especially because sst 2 receptor has also been involved in the regulation of $\mathrm{GH}$ secretion in both rodent (30) and human (31) pituitaries.

\section{Somatostatin and cancer}

The capacity of SRIF to negatively regulate cell proliferation through both indirect and direct mechanisms has repeatedly been reported. Indirect actions include the inhibition of secretion of growth-promoting hormones and growth factors stimulating the growth of various cell types. For example, the ability of SRIF to inhibit insulin-like growth factor-I expression and serum levels represents the rationale for its use in an adjuvant therapy for tamoxifen in the treatment of breast cancer (32). However, it should be stressed that the recent clinical trials (phase III) indicated that adding somatostatin analogs to tamoxifen do not increase the therapeutic benefit of tamoxifen in the treatment of advanced breast carcinoma (33). Besides, the capacity of SRIF to inhibit angiogenesis is of potential clinical relevance for the indirect control of tumor cell growth $(16,34)$.

The ability of SRIF to control cell number by both inhibiting cell division and triggering programmed cell death by apoptosis has been demonstrated in vitro. Thus, it has been shown that SRIF inhibits the proliferation of cell lines transfected to express sst1, sst 2 or sst 5 receptors $(35,36)$. The underlying mechanisms involve the activation of SHP tyrosine phosphatases and ERK pathways $(35,37,38)$. The induction of apoptosis by SRIF in the cell lines studied is mediated by sst2 (39) and sst3 (40). SRIF-mediated inhibition of cell division and the triggering of cell death are the features that are currently used therapeutically in order to achieve a direct control of tumor growth by this peptide. Obviously such an approach is only possible in those cancers expressing SRIF receptors. This is the case for neuroendocrine, gastro-entero-pancreatic, brain, breast, prostate and lung cancers. In addition to the relevant therapeutic applications, a SRIF analog such as indium $^{111}$-labeled octreotide is routinely used for diagnostic purposes in cancers displaying SRIF receptors. SRIF receptor scintigraphy has indeed proven valuable in the detection of a range of human cancers and their metastases (41).

It should be stressed that more than $80 \%$ of the carcinoid tumors studied display sst 2 and sst5 receptors (sst5 being less abundant than sst2) (for review, see 16). Besides, such a pattern of receptor expression by tumors brings, a posteriori, the rationale for the efficiency of anti-cancerous SRIF analogs (octreotide, lanreotide, vapreotide). The latter analogs had been developed before the molecular cloning of SRIF receptors, based on their high efficiency to inhibit SRIF-relevant hormone secretions and their resistance to enzymatic degradation after subcutaneous administration (for historical overview, see 42). However, it should be kept in mind that the level and pattern of expression of SRIF receptors vary greatly among different carcinomas. Indeed, the efficacy of clinically used SRIF analogs has been explicitly proven only for the treatment of neuroendocrine tumors. In addition, the sst2-preferential radiolabeled SRIF analogs, such as ${ }^{177} \mathrm{Lu}$-octreotate, appear very promising for the treatment of neuroendocrine gastro-entero-pancreatic tumors (43). Importantly, the loss of a specific type of SRIF receptors (sst 2 in particular) has been observed in tumors other than those of neuroendocrine origin (e.g. pancreatic and prostatic adrenocarcinomas). It might explain the lack of therapeutic benefit of clinically used SRIF analogs in these pathologies (44). Altogether, these data emphasize the need for further development of new SRIF analogs (additional to sst2/sst5 preferential analogs) for the purpose of anticancerous therapies. More generally and considering the new modalities of somatostatin actions in terms of receptor dimerization discussed below, development of hybrid somatostatinergic molecules appears particularly promising in the perspective of clinical treatment of pituitary tumors (adenomas). Indeed, almost all $\mathrm{GH}$-secreting adenomas express sst 2 and sst 5 receptors whereas prolactinomas (i.e. prolactin (PRL)-secreting adenomas) express predominantly sst5 receptor. Although octreotide and lantreotide have been shown to be able to suppress $\mathrm{GH}$ secretion successfully in GH-secreting adenomas some of these tumors are refractory to this treatment as are the majority of prolactinomas. The development of sst $2 /$ sst 5 bi-specific analogs on the one hand, and of somatostatin/dopamine hybrid molecules on the other hand, pointed to their great efficacy to suppress in vitro $\mathrm{GH}$ secretion from refractory GH-secreting adenomas and PRL secretion from prolactinomas respectively (reviewed in $45,46)$. The example of adenomas, therefore, nicely illustrates how the integration of the new concepts on 
modalities of somatostatin actions (c.f. below) in strategies used for the development of new SRIF analogs might be a powerful tool for the achievement of the better control of the size and hypersecretion from sst receptor-expressing neuroendocrine tumors.

\section{New modalities of somatostatin actions: juxtacrine effects}

Such a plethora of physiological and pathological effects of SRIF are mediated through classical (neuro)hormonal, paracrine and autocrine pathways. A growing body of evidence now suggests that SRIF may also act in a juxtacrine manner, through a variant of cellto-cell interaction. For example, during antigen presentation, an antigen presenting cell (APC) such as a macrophage is very close to the $\mathrm{CD} 4^{+} \mathrm{T}$-lymphocyte. This spatial proximity is a consequence of T-cell receptor (TCR) interaction with antigenic peptide presented in the context of major histocompatibility complex (MHC) class II molecule occurring simultaneously to $\mathrm{CD}^{+}{ }^{+}$interaction with $\mathrm{MHC}$ class II molecule. In mice, activated macrophages are producing SRIF (47) whereas T-lymphocytes express SRIF receptors (48). Thus, intimate contact between the two cells during the process of antigen presentation may allow SRIF to act on T-lymphocytes in a juxtacrine manner. Interaction of SRIF with its receptors is sufficient to trigger the cytokine production by T-cells (49). SRIF might therefore directly induce the secretory response of activated T-cells. In addition, SRIF might modulate the antigen-induced response (proliferation and cytokine secretion) by either potentiating or attenuating it (for review see 1). In consequence, SRIF secreted by APC should be considered as a costimulatory signal acting through a juxtacrine mode in a fashion similar to the B7 ligand expressed on APC plasma membrane. Consistently, SRIF receptors (expressed on the plasma membranes of T-lymphocytes) could be seen as functionally analogous to the costimulatory receptor CD28 (Fig . 1). It should, however, be noted that in humans, although the principle of the costimulatory role exerted through SRIF receptors appears applicable, the ligand responsible for activation of these receptors is CST rather than SRIF itself. Indeed, we $(50,51,52)$ and others $(53,54)$ were able to identify different types of sst receptors (with consensus being reached for sst3) on human normal and leukemia T-lymphocytes. But, in contrast to murine macrophages, human macrophages and dendritic cells express CST $(6,7)$.

Another example of juxtacrine actions of SRIF is seen in mammalian testes. Given the intimate contact between Sertoli cells and male germ cells, it has been hypothesized that regulatory factors produced by Sertoli cells might act on spermatogonia through a juxtacrine mode of action and vice-versa. The recently

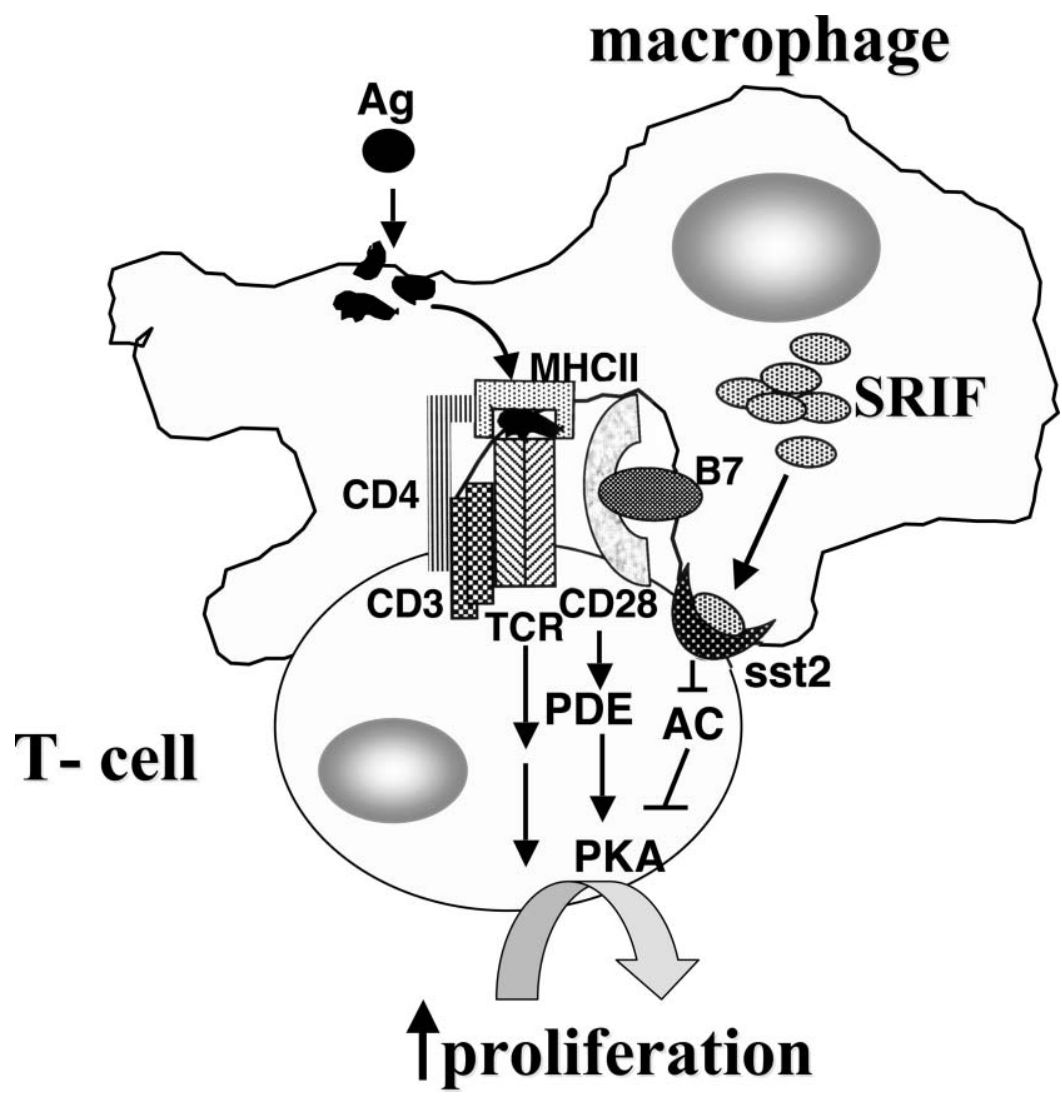

Figure $1 \mathrm{~A}$ model according to which somatostatin (SRIF) receptors (sst2) might be considered as T-lymphocyte receptor for costimulatory signal SRIF through a juxtracrine communication between murine T-lymphocyte and macrophage. Interaction between SRIF produced by antigen presenting cell (APC, here activated macrophage) and its receptor sst2 inhibits $(\perp)$ adenylyl cyclase (AC). This inhibition might be additive in terms of a decrease in intracellular cAMP concentration to that subsequent to the activation of phosphodiesterase (PDE) after CD28 receptor interaction with B7 ligand expressed on APC plasma membrane. Altogether, these interactions lead to protein kinase $A(P K A)$ inhibition. Given that elevated PKA activity exerts a tonic restraint on lymphocyte proliferation, PKA inhibition results in the release of the blockage. The subsequent increase of proliferation $(\uparrow)$ might synergize with phospho-tyrosine-pathway-dependent induction of prolferation initiated through T-cell receptor (TCR)/antigenic $(\mathrm{Ag})$ peptide interaction on the one hand and CD4 receptor/MHC II (major histocompatibility complex, class II) molecule interaction on the other hand. 
demonstrated interaction of Sertoli cells and spermatids (post-meiotic, relatively differentiated male germ cells) through Sertoli cell-derived androgen-binding protein (ABP) which, in turn, triggers the expression of spermatid-specific transcription factors, well illustrates testicular juxtacrine interactions (55). In this context, we have recently reported that in immature porcine testis, spermatogonia (male germ-line stem cells) produce SRIF whereas both spermatogonia and Sertoli cells express sst 2 receptors $(56,57)$. Spermatogonia and Sertoli cells are in intimate contact by which the Sertoli cell provides physical, regulatory and nutritive support to spermatogonia. We were able to demonstrate that such an intimate contact has direct functional consequences on both cell types. Thus, SRIF inhibits stem cell factor (SCF) expression by Sertoli cells concurrently with the inhibition of SCF-induced spermatogonia proliferation (56). In this example, juxtacrine and autocrine actions of SRIF are combined to allow orchestrated inhibition of spermatogonia proliferation through both direct and indirect effects. SRIF-mediated inhibition of spermatogonia proliferation via sst 2 receptor underlies the peptide's direct effects in an autocrine manner whereas the inhibition of SCF expression through the same receptor type allows an indirect control of spermatogonia proliferation in a juxtacrine manner. Indeed, SCF is the major mitogenic and survival factor for spermatogonia $(58,59)$.

The superposition of different modes of action of a single peptide (SRIF) through a single type of receptor (sst2) provides, therefore, a fine-tuning of a given physiological response such as spermatogonia proliferation (Fig. 2). It remains to be determined, however, if the paradigm of juxtacrine actions of SRIF as proposed here for porcine testes might be applicable to sst3, sst 4 and/or sst 5 receptor interaction with intra-testicular SRIF in human testes. Indeed, we previously reported the expression of these three receptor types in normal human testes (60). In addition, the presence of SRIF in human testicular homogenates has been demonstrated (61) but the precise cell types expressing SRIF are, as yet, unknown.

\section{New modalities of somatostatin actions: receptor dimerization}

The concomitant expression of multiple SRIF receptors by a single cell has been well established (e.g. in pituitary (62) and pancreatic (63) cells). By analogy to other types of G-protein-coupled receptors, such coexpression of different types of SRIF receptors raised the possibility for homo- and heterodimerization between them. During the last few years such interactions have indeed been demonstrated, at least in heterologous cell-expression systems such as epithelial and fibroblast cells. Thus, the homodimerization of sst2, sst3 (64) and sst5 $(65,66,67)$ has been reported and, at least in the case of sst5, it has been explicitly

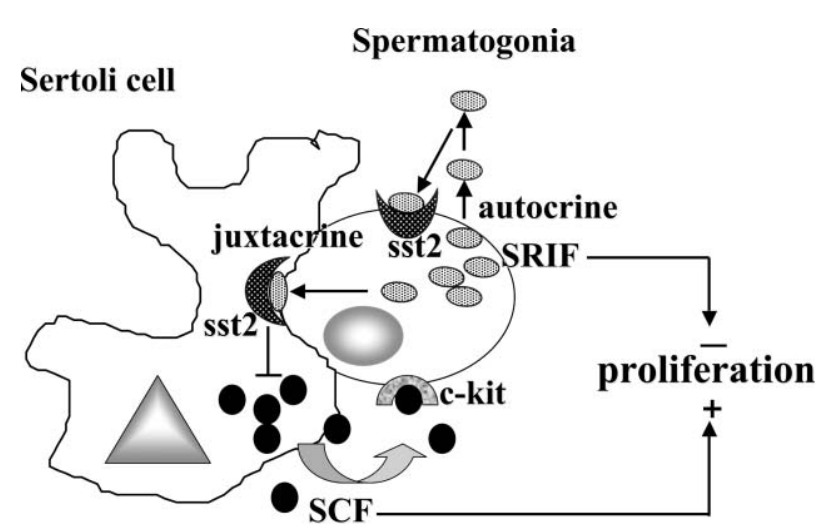

Figure 2 A model for juxtacrine interactions between spermatogonia and Sertoli cell via somatostatin (SRIF) in immature porcine testis. Such interaction is plausible because spermatogonia produce SRIF and Sertoli cells express sst2 receptors. Activation of sst2 receptor by SRIF binding leads to a diminished expression of stem cell factor (SCF) expression by Sertoli cells. Because SCF is the main mitogenic factor for these cells, such inhibition of SCF expression is associated with a decrease in spermatogonia proliferation. This juxtacrine regulation of spermatogonia proliferation might be superposed to a putative autocrine control via sst2 receptors expressed by spermatogonia themselves. Indeed, given the anti-proliferative actions of SRIF, the autocrine interaction SRIF/sst2 receptor might directly inhibit spermatogonia proliferation.

demonstrated that it is SRIF induced. However, the homodimerization of either sst1 (68) or sst4 has not been revealed so far. The heterodimerization of sst2 and sst $3(64)$ as well as of sst 1 and sst $5(65,67)$ has also been reported. The heterodimerization with other types of G-protein-coupled receptors such as muopioid and dopaminergic D2 has been reported for sst2 (69) and sst5 (66) respectively.

These different types of receptor oligomerization lead to the formation of 'poly'-receptors with qualitatively new characteristics in terms of receptor affinity for ligand binding, efficiency of the relevant signal transduction and receptor trafficking. For example, the affinity for the sst3-selective ligand is greatly diminished in the case of the sst $2 /$ sst 3 complex, it is not altered for the sst2-selective ligand in the case of the sst2/sst3 complex and is greatly enhanced for the sst5-selective ligand in the case of the sst5/D2 receptor complex. Similarly, the effect of receptor oligomerization on adenylyl cyclase and ERK pathways varies greatly depending on the receptor partners. Thus the transduction via sst3 is silenced by its heterodimerization with sst2 (64) whereas the sst2-selective agonists activate the ERK pathway much more significantly through the sst2/mu-opioid receptor dimer than through the monomeric sst2. The latter is evident even if the 'poly'-receptor has a lower affinity for sst 2 agonists than the sst2 monomer (69). Finally, at least in some circumstances, the receptor oligomerization alters the dynamics of receptor internalization. For example, sst5-selective ligand-induced internalization of sst5 receptor is decreased when it is complexed with sst1 (67). Similarly, 
sst 3 is not internalized by sst3-selective ligands when it is dimerized with sst2 (64).

The new characteristics conferred to SRIF 'poly'receptors by oligomerization of the individual sst receptors might become valuable pharmacological tools. Indeed, a synthetic bi-specific ligand BIM-23244 (i.e. sst 2 and sst 5 preferential) is able to inhibit GH secretion by somatotrope adenomas with an affinity better than that of octreotide. Moreover, this agonist is efficient even in octreotide-resistant adenomas probably because sst 5 'prolongs' the action of sst2-selective component on the sst $2 /$ sst 5 heterodimer due to the slower internalization and the faster re-sensibilization than the relevant sst2 kinetics (70). Similarly, chimeric SRIF/dopaminergic molecules (BIM-23A387) acting apparently through sst2/D2 receptor dimers are more potent in suppressing GH and PRL secretions from human pituitary somatotrope adenoma cells (71).

The combinatorial engagement of different receptor subtypes by SRIF itself or by chimeric ligands contributes to the increase in diversity of the cell receptor equipment and increases the molecular basis for the pleiotropy of SRIF biological actions (Fig. 3). However, it should be kept in mind that homo- and heterodimerization of SRIF receptors has so far been documented only in cell lines and that both remain to be established in non-transformed cells. In this context, the data of Baragli and co-workers (72) pointing to the heterodimerization of dopamine D2 receptor and somatostatin
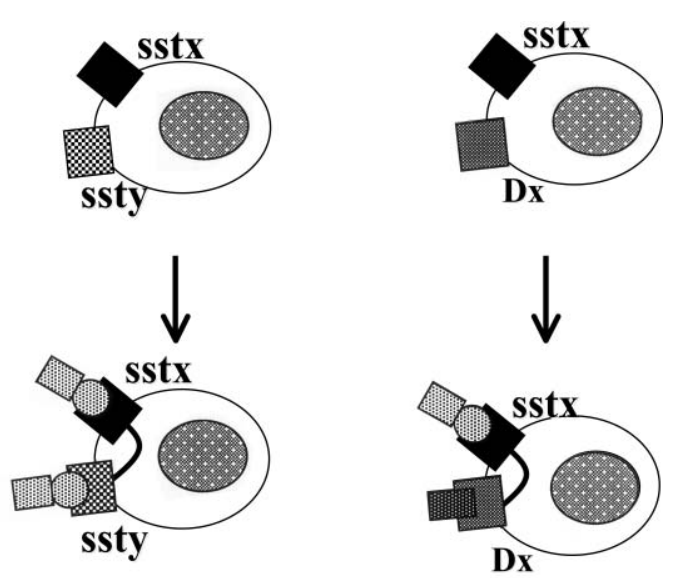

SRIF DA

Figure 3 Receptor oligomerization as a source of diversity. Receptor dimerization may be a consequence of SRIF binding to either different SRIF receptor isoforms (sstx and ssty) or can result from dimerization of sstx receptor and another GPCR (Dx) activated by an another ligand (DA). In both cases receptor interaction leads to the alteration in receptor affinity, trafficking and signal transduction. The so formed 'poly'-receptor has the qualitatively novel characteristics that might explain the fact that a small number of SRIF receptor isoforms mediates a panoply of SRIF actions. sst2 receptors in primary human astrocytes appear very relevant.

\section{New avenues of specificity}

The specificity of SRIF actions on a particular cell is achieved through a combination of receptor isoform expression by the cell in question. An increasing body of evidence now suggests that this specificity can be modulated by different factors since the pattern of receptor isoform expression displays some degree of plasticity. Schematically, the factors impinging on the specificity of SRIF actions may be considered as temporal, environmental and functional.

The recently documented shift from sst $2 \mathrm{~A}$ to sst3 receptor expression in maturating thymocytes represents an example of the putative temporal correlates of SRIF specificity (73). Indeed, immature CD2 + CD3 - thymocytes are actively proliferating cells in the process of differentiation via TCR rearrangement, whereas mature, differentiated CD3+ thymocytes undergo apoptosis during positive and negative selection occurring in this primary lymphoid organ. The observed developmentally regulated shift in sst-receptor expression therefore suggests that SRIF might be involved in $\mathrm{CD} 2+\mathrm{CD} 3-$ cell differentiation through the sst $2 \mathrm{~A}$ receptor while it might regulate $\mathrm{CD} 3+$ cell selection by apoptosis via sst3 (73).

Modulation of SRIF specificity by environmental factors has not been investigated yet either in non-transformed cells (in vitro) or in vivo. However, based on the data on SRIF receptor oligomerization obtained in cell expression systems, it is reasonable to assume that the simultaneous presence of other ligands (e.g. dopamine, opioids) and activation of other GPCR receptors by these ligands (e.g. D2-dopaminergic, $\mu$ - and $\delta$ opioid receptors) might be the origin of subsequent receptor oligomerization, thus conferring a different pattern of receptor engagement and different functional read-out of SRIF actions depending on the presence or absence of other ligands (Fig. 4). These considerations, if confirmed by experimental evidence in vivo, would have important conceptual implications. In this case, the concept of specificity of a given ligand depending on the pattern of the relevant receptor expression should then be enlarged on the pattern of differential receptor engagement in the presence of different combination of other ligands.

Finally, the functional state of the cell is also responsible for the alteration of SRIF specificity. For instance, both normal and tumoral pituitary lactotropes express sst 2 and sst5 receptors. However, prolactin secretion is predominantly inhibited by, respectively, sst 2 and sst5 receptor in normal embryonic and tumoral lactotropes $(74,75)$. Therefore, in the course of pathogenesis (i.e. transition from physiological versus pathological states in a particular cell) there might also be a shift in the type of receptor involvement in a 


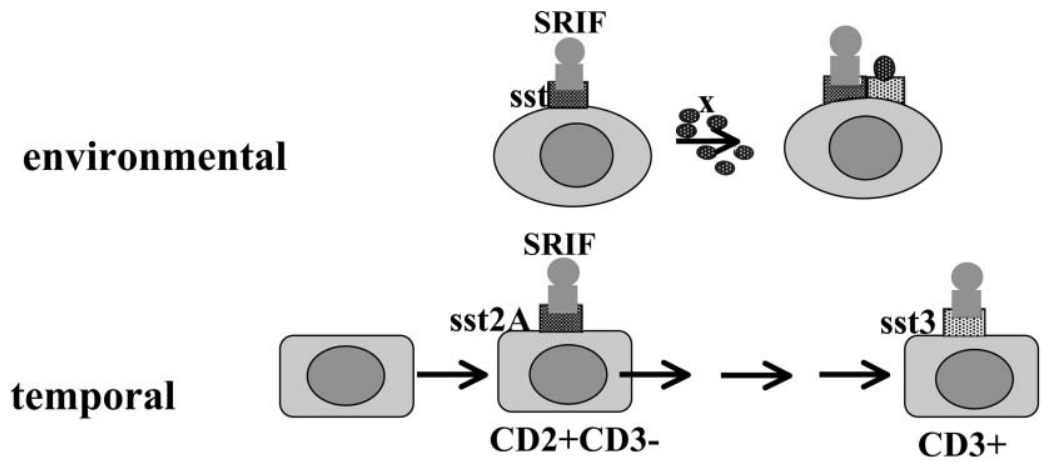

functional state

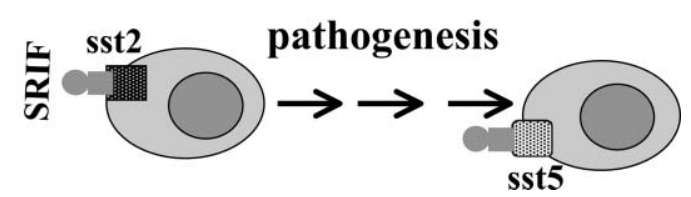

Figure 4 New avenues of SRIF specificity. The specificity of SRIF actions might be affected by environmental, temporal and functional parameters. Environmental factors that might alter the specificity involve, for example, the presence of another ligand $(X)$ capable of activating receptors that can dimerize (i.e. dopaminergic, opioid) with sst receptors. In this case, the specificity of SRIF actions mediated by receptor heterodimer would be different from that resulting from exclusive activation of sst receptor by SRIF. Temporal parameters involve, for example, a developmentally regulated shift from one (sst2A) to another (sst3) receptor isoform expression during thymocyte maturation from CD2+CD3 - to CD3+ cells. Finally, in some pathological states, the same SRIF action (e.g. inhibition of prolactin secretion) might be mediated by a receptor (sst5) which is irrelevant in the physiological state. given cellular response (i.e. prolactin secretion in this example). Such a shift might occur without obvious alteration in the pattern of receptor expression by the cell (Fig. 4).

Overall, the modulation of the effects of SRIF by temporal, environmental and cell functional state factors leads to the additional diversification of its specificity.

\section{Conclusions}

Some novel physiological actions have been discovered for the natural peptides such as SRIF during the last two decades. Indeed, it is now well accepted that they are produced by pathogen-activated immune cells (e.g. macrophages) and subsequently activate other types of immune cells (e.g. T-lymphocytes) in an orchestrated succession of cell-to-cell interactions inherent to the immune system and indispensable for mounting an efficient immune response. Natural peptides are therefore the functional equivalent of cytokines, the latter being, until recently, considered as unique immunopeptides. Indeed, these two classes of chemical messengers share different modes of action (autocrine, paracrine and, more recently demonstrated, juxtacrine). More importantly, these modalities of action appear general (i.e. not limited only to the immune system) considering, for example, SRIF actions in spermatogoniaSertoli cell communication in testes.

In addition, the ligand-induced receptor dimerization, until recently considered as exclusive for, and inherent to, the activation of cytokine and growth factor receptors, has now been demonstrated for SRIF-induced receptor oligomerization. Thus oligomerization also appears as a general principle of receptor activation, irrespective of the class of receptor and the nature of the ligand. In the particular case of SRIF, the ligand-induced formation of receptors of higher order should now be assessed systematically in all of its physiological targets. Indeed, virtually all of them co-express more than one sst receptor and obviously express other types of G-protein-coupled receptors.

In conclusion, these 'novel' modalities of SRIF action in terms of juxtacrine actions and/or receptor oligomerization contribute to increase the functional diversity of its physiological effects and might further help to explain how a limited number of receptors might underlie a plethora of its biological roles. We are convinced that the better understanding of such 'novel' modalities of SRIF actions would soon become a paradigm for the discovery of similar modalities of action for other natural peptides that, in time, might open new therapeutic avenues.

\section{Acknowledgements}

This review is posthumously dedicated to Nathalie Giannetti for her precious contribution to the realization of the relevant projects. We would also like to thank Dr R Rasolonjanahary for the critical reading of the manuscript.

\section{References}

1 Krantic S. Peptides as regulators of the immune system: emphasis on somatostatin. Peptides 200021 1941-1964.

2 De Lecea L, Criado J, Prospero-Garcia O, Gautvik K, Schweitzer P, Danielson P, Dunlop C, Siggins G, Henriksen S \& Sutcliffe J. A cortical neuropeptide with neuronal depressant and sleep-modulating properties. Nature $1996 \mathbf{3 8 1} 242-245$.

3 Dalm V, Van Hagen M, De Krijger R, Kros J, Van Koetsveld P, Van Der Lely A, Lamberts S \& Hofland L. Distribution pattern of somatostatin and cortistatin mRNA in human central and peripheral tissues. Clinical Endocrinology 200460 625-629.

4 Papotti M, Tarabra E, Allia E, Bozzalla-Cassione F, Broglio F, Deghenghi R, Ghigo E \& Muccioli G. Presence of cortistatin in 
the human pancreas. Journal of Endocrinological Investigation 200326 RC15-RC18.

5 Notas G, Kolios G, Mastrodimou N, Kampa M, Vasilaki A, Xidakis C. Castanas E, Thermos K \& Kouroumalis E. Cortistatin production by HepG2 human hepatocellular carcinoma cell line and distribution of somatostatin receptors. Journal of Hepatology $200440792-798$.

6 Lichtenauer-Kaligis E, Dalm V, Van Hagen M, Lamberts S \& Hofland L. Differential expression of somatostatin receptor subtypes in human peripheral blood mononuclear cell subsets. European Journal of Endocrinology 2004150 567-577.

7 Dalm V, Van Hagen M, Van Koetsveld P, Achilefu S, Houtsmuller A, Pols D, Van Der Lely A, Lamberts S \& Hofland L. Expression of somatostatin, cortistatin and somatostatin receptors in human monocytes, macrophages and dendritic cells. American Journal of Physiology, Endocrinology and Metabolism $2003 \mathbf{2 8 5}$ E344-E353.

8 Moller L, Stidsen C, Hartmann B \& Holst J. Somatostatin receptors. Biochimica et Biophysica Acta $2003 \mathbf{1 6 1 6} 1-84$.

9 Dalm V, Van Hagen M, Van Koetsveld P, Langerak A, Van Der Lely A, Lamberts S \& Hofland L. Cortistatin rather than somatostatin as a potential endogenous ligand for somatostatin receptors in the human immune system. Journal of Clinical Endocrinology and Metabolism 200388 270-276.

10 Robas N, Mead E \& Fidock M. MrgX2 is a high potency cortistatin receptor expressed in dorsal root ganglion. Journal of Biological Chemistry $2003 \mathbf{2 7 8} 44400-44404$.

11 Breder C, Yamada Y, Yasuda K, Seino S, Saper C \& Bell G. Differential expression of somatostatin receptor subtypes in brain. Journal of Neuroscience $1992123920-3934$.

12 Bruno JF, Xu Y, Song J \& Berelowitz M. Tissue distribution of somatostatin receptor subtype messenger ribonucleic acid in the rat. Endocrinology $19931332561-2567$.

13 Patel YC. Somatostatin and its receptor family. Frontiers in Neuroendocrinology $199920157-198$.

14 Dalm V, Hofland L, Ferone D, Croxen R, Lamberts S \& van Hagen PM. The role of somatostatin and somatostatin analogs in the pathophysiology of the human immune system. Journal of Endocrinological Investigation 200326 94-102.

15 Bruns C, Briner U, Lewis GGMT \& Weckbecker G. SOM230: a new somatostatin peptidomimetic with broad SRIF receptor binding and a unique inhibitory profile. European Journal of Endocrinology $2002 \mathbf{1 4 6} 707-716$.

16 Ferjoux G, Bousquet C, Cordelier P, Benali N, Lopez F, Rochaix P, Buscail L \& Susini C. Signal transduction of somatostatin receptors negatively controlling cell proliferation. Journal of Physiology (Paris) $200094205-210$.

17 Lahlou H, Guillermet J, Hortala M, Vernejoul F, Pyronnet S, Bousquet C \& Susini C. Molecular signaling of somatostatin receptors. Annals of the New York Academy of Sciences 2004 $1014121-131$.

18 Videau C, Hochgeschwender U, Kreienkamp H, Brennan M, Viollet C, Richter D \& Epelbaum J. Characterization of $\left[{ }^{125}\right.$ I]TyrODTrp-8 somatostatin binding in sst1- to sst4- and SRIF-gene-invalidated mouse brain. Naunyn Schmiedeberg's Archives of Pharmacology $2003 \mathbf{3 6 7} 562-571$.

19 Strowski M, Kohler M, Chen H, Trumbauer M, Li Z, Szalkowski D, Gopal-Truter S, Fisher J, Schaeffer J, Blake A, Zhang B \& Wilkinson H. Somatostatin receptor subtype 5 regulates insulin secretion and glucose homeostasis. Molecular Endocrinology $20031793-106$.

20 Allen J, Hathway G, Clarke N, Jowett M, Topps S, Kendrick K, Humphrey P, Wilkinson L \& Empson P. Somatostatin receptor 2 knock-out/lacZ knock-in mice show impaired motor coordination and reveal sites of somatostatin action within the striatum. European Journal of Neuroscience 200317 1881-1895.

21 Dutar P, Vaillend C, Viollet C, Billard J, Potier B, Carlo A, Ungerer A \& Epelbaum J. Spatial learning and synaptic hippocampal plasticity in type 2 somatostatin receptor knock-out mice. Neuroscience $2002112455-466$.
22 Viollet C, Vaillend C, Videau C, Bluet-Pajot MT, Ungerer A, L'Heritier A, Kopp P, Potier B, Billard J, Schaeffer J, Smith R, Rohrer S, Wilkinson H, Zheng H \& Epelbaum J. Involvement of sst2 somatostatin receptor in locomotor, exploratory activity and emotional reactivity in mice. European Journal of Neuroscience $2000123761-3770$.

23 Martinez V, Curi A, Torkian B, Schaeffer J, Wilkinson H, Walsh J \& Tache Y. High basal gastric acid secretion in somatostatin receptor subtype 2 knockout mice. Gastroenterology 1998114 1125-1132.

24 Piqueras L, Tache Y \& Martinez V. Somatostatin receptor 2 mediates bombesin-induced inhibition of gastric acid secretion in mice. Journal of Physiology (Paris) 2003549 889-901.

25 Tirone T, Norman M, Moldovan S, Demayo F, Wang X \& Brunicardi F. Pancreatic somatostatin inhibits insulin secretion via SSTR5 in the isolated perfused mouse pancreas model. Pancreas 200326 67-73.

26 Mitra S, Mezey E, Hunyady B, Chamberlain L, Hayes E, Foor F, Wang Y, Schonbrunn A \& Schaeffer J. Colocalization of somatostatin receptor sst5 and insulin in rat pancreatic beta-cells. Endocrinology $19991403790-3796$.

27 Ludvigsen E, Olsson R, Stridsberg M, Janson E \& Sandler S. Expression and distribution of somatostatin receptor subtypes in the pancreatic islets of mice and rats. Journal of Histochemistry and Cytochemistry 200452 391-400.

28 Casini G, DalMonte M, Petrucci C, Gambellini G, Grouselle D, Allen J, Kreienkamp H, Richter D, Epelbaum J \& Bagnoli P. Altered morphology of rod bipolar cell axonal terminals in the retinas of mice carrying genetic deletion of somatostatin subtype receptor 1 or 2. European Journal of Neuroscience 200419 $43-54$.

29 Kreienkamp H, Akgun E, Baumeister H, Meyerhof W \& Richter D. Somatostatin receptor subtype 1 modulates basal inhibition of growth hormone release in somatotrophs. FEBS Letters $1999462464-466$.

30 Lanneau C, Bluet-Pajot M, Zizzari P, Csaba Z, Dournaud P, Helboe L, Hoyer D, Pellegrini E, Tannenbaum G, Epelbaum J \& Gardette R. Involvement of the sst1 somatostatin receptor subtype in the intrahypothalamic neuronal network regulating growth hormone secretion: an in vitro and in vivo antisense study. Endocrinology $2000141967-979$.

31 Ren S, Taylor J, Dong J, Yu R, Culler M \& Melmed S. Functional association of somatostatin receptor subtypes 2 and 5 in inhibiting human growth hormone secretion. Journal of Clinical Endocrinology and Metabolism $2003 \mathbf{8 8} 4239-4245$.

32 Pollak M. Enhancement of the anti-neoplastic effects of tamoxifen by somatostatin analogs. Digestion 199657 (Suppl 1) $29-33$.

33 Bajetta E, Procopio G, Ferrari L, Martinetti A, Zilembo N, Catena L, Alu M, Demlla T, Alberti D \& Buzzoni R. A randomized, multicenter prospective trial assessing long-acting release octreotide pamoate plus tamoxifen as a first line therapy for advanced breast carcinoma. Cancer 200294 299-304.

34 Dasgupta P. Somatostatin analogues: multiple roles in cellular proliferation, neoplasia and angiogenesis. Pharmacology and Therapeutics $200410261-85$.

35 Buscail L, Delesque N, Estève JP, Saint-Laurent N, Prats H, Clerc P, Robberecht P, Bell GI, Liebow C, Schally A, Vaysse N \& Susini C. Stimulation of tyrosine phosphatase and inhibition of cell proliferation by somatostatin analogues: mediation by human somatostatin receptor subtypes SSTR1 and SSTR2. PNAS $1994912315-2319$.

36 Buscail L, Estève JP, Saint-Laurent N, Bertrand V, Reisine T, O'Carroll AM, Bell GI, Schally A, Vaysse N \& Susini C. Inhibition of cell proliferation by the somatostatin analogue RC-160 is mediated by somatostatin receptor subtype SSTR2 and SSTR 5 through different mechanisms. PNAS 199592 1580-1584.

37 Lahlou H, Saint-Laurent N, Esteve J, Eychene A, Pradayrol L, Pyronnet S \& Susini C. sst2 somatostatin receptor inhibits cell proliferation through Ras-, Rap1-, and B-Raf-dependent ERK2 
activation. Journal of Biological Chemistry $2003 \mathbf{2 7 8}$ 39356-39371.

38 Cordelier P, Esteve J, Bousquet C, Delesque N, O'Carrol A, Schally A, Vaysse N, Susini C \& Buscail L. Characterization of the antiproliferative signal mediated by somatostatin receptor subtype sst5. PNAS $1997949343-9348$.

39 Teijeiro R, Rios R, Costoya J, Castro R, Bello J, Devesa J \& Arce V. Activation of human somatostatin receptor 2 promotes apoptosis through a mechanism that is independent from induction of p53. Cell Physiology and Biochemistry 200212 31-38.

40 Sharma K, Patel YC \& Srikant CB. Subtype-selective induction of wild-type p53 and apoptosis, but not cell cycle arrest, by human somatostatin receptor 3. Molecular Endocrinology 199610 $1688-1696$.

41 Reubi J. Peptide receptors as molecular targets for cancer diagnosis and therapy. Endocrine Reviews 200324 389-427.

42 Lamberts S, Van Der Lely A \& Hofland L. New somatostatin analogs: will they fulfil old promises? European Journal of Endocrinology $2002146701-705$.

43 Kwekkeboom D, Bakker W, Kam B, Teunissen J, Kooij P, De Herder W, Feelsers R, Van Eijck C, De Jong M, Srinivasan A, Erion J \& Krenning E. Treatment of patients with gastroentero-pancreatic (GEP) tumours with the novel radiolabeled somatostatin analogue [177Lu-DOTA(0), Tyr3]octreotate. European Journal of Nuclear Medicine and Molecular Imaging 200330 417-422.

44 Hejna M, Schmidinger M \& Readerer M. The clinical role of somatostatin analogs: much ado about nothing? Annals of Oncology 200213 653-668.

45 Shimon I. Somatostatin receptors in pituitary and development of somatostatin receptor subtype-selective analogs. Endocrine $200320265-269$.

46 Hofland L \& Lamberts S. Somatostatin receptors in pituitary function, diagnosis and therapy. Frontiers in Hormone Research 200432 235-252.

47 Weinstock J, Blum A \& Malloy T. Macrophages within the granulomas of murine schistosomiasis mansoni are a source of a somatostatin 1-14 like molecule. Cellular Immunology 1990 $131381-388$

48 Elliott DE, Metwali A, Blum M, Sandor M, Lynch R \& Weinstock JV. T lymphocytes isolated from the hepatic granulomas of schistosome-infected mice express somatostatin receptor subtype II (SSTR2) messenger RNA. Journal of Immunology 1994153 $1180-1186$.

49 Levite M. Neuropeptides, by direct interaction with T cells, induce cytokine secretion and break the commitment to a distinct T helper phenotype. PNAS 199895 12544-12549.

50 Cardoso A, El Ghamrawy C, Gautron JP, Horvat B, Gautier N, Enjalbert A \& Krantic S. Somatostatin increases mitogeninduced IL-2 secretion and proliferation of human Jurkat Tcells via sst3 receptor isotype. Journal of Cellular Biochemistry $19986862-73$.

51 El Ghamrawy C, Rabourdin-Combe C \& Krantic S. sst5 somatostatin receptor mRNA induction by mitogenic activation of human T-lymphocytes. Peptides 199920 305-311.

52 Giannetti N, Horvat B, Gautier N, El Ghamrawy C, RabourdinCombe C, Enjalbert A \& Krantic S. Somatostatin-dependent adenylyl cyclase activity in non-activated and mitogen-activated human T cells: evidence for uncoupling of sst3 receptor from adenylyl cyclase. Journal of Cellular Biochemistry 199972 221-231.

53 Ishihara S, Hassan S, Kinoshita Y, Moriyama N, Fukuda R, Maekawa T, Okada A \& Chiba T. Growth inhibitory effects of somatostatin on human leukemia cell lines mediated by somatostatin receptor subtype 1. Peptides 199920 313-318.

54 Van Hagen PM, Hofland LJ, Ten Bokum AMC, Lichtenauer-Kaligis EGR, Kwekkeboom DJ, Ferone D \& Lamberts SWJ. Neuropeptides and their receptors in the immune system. Annals of Medicine 199931 (Suppl 2) 15-22.
55 Della-Maria J, Gerard A, Franck P \& Gerard H. Effects of androgen-binding protein (ABP) on spermatid Tnp1 gene expression in vitro. Molecular and Cellular Endocrinology 2002198 131-141.

56 Goddard I, Bauer S, Gougeon A, Lopez F, Giannetti N, Susini C, Benahmed M \& Krantic S. Somatostatin inhibits stem cell factor messenger RNA expression by Sertoli cells and stem cell factorinduced DNA synthesis in isolated seminiferous tubules. Biology of Reproduction $2001 \mathbf{6 5} 1732-1742$.

57 Fombonne J, Csaba Z, Von Boxberg Y, Valayer A, Rey C, Benahmed M, Dournaud P \& Krantic S. Expression of somatostatin receptor type-2 (sst2A) in immature porcine Leydig cells and a possible role in the local control of testosterone secretion. Reproductive Biology and Endocrinology 20031 19-27.

58 Feng L, Ravindranath N \& Dym M. Stem cell factor/c-kit upregulates cyclin D3 and promotes cell cycle progression via the phosphoinositide 3-kinase/p70 S6 kinase pathway. Journal of Biological Chemistry $200027525572-25576$.

59 Yan W, Souminen J \& Toppari J. Stem cell factor protects germ cells from apoptosis in vitro. Journal of Cell Science $2000 \mathbf{1 1 3}$ $161-168$.

60 Baou N, Bouras M, Droz JP, Benahmed M \& Krantic S. Evidence for a selective loss of somatostatin receptor subtype expression in male germ cell tumors of seminoma type. Carcinogenesis 2000 $21805-810$.

61 Sasaki A \& Yoshinaga K. Immunoreactive somatostatin in male reproductive system in humans. Journal of Clinical Endocrinology and Metabolism $198968996-999$.

62 Kumar U, Laird D, Srikant C, Escher E \& Patel Y. Expression of the five somatostatin receptor (SSTR1-SSTR5) subtypes in rat pituitary somatotrophes: quantitative analysis by double-labeled immunofluorescence confocal microscopy. Endocrinology 1997 138 4473-4476.

63 Kumar U, Sasi R, Suresh S, Patel A, Thangaraju M, Metrakos P, Patel S \& Patel Y. Subtype-selective expression of the five somatostatin receptors (hSSTR1-5) in human pancreatic islet cells: a quantitative double-labeled immunohistochemical analysis. Diabetes $1999 \mathbf{4 8} 77-85$.

64 Pfeiffer M, Koch T, Schroder H, Klutzny M, Kirscht S, Kreienkamp H, Holt V \& Schulz S. Homo- and heterodimerization of somatostatin receptor subtypes. Inactivation of sst3 receptor function by heterodimerization with sst2A. Journal of Biological Chemistry 2001276 14027-14036.

65 Patel R, Kumar U, Lamb D, Eid J, Rocheville M, Grant M, Rani A, Hazlett T, Patel S, Gratton E \& Patel Y. Ligand binding to somatostatin receptors induces receptor-specific oligomer formation in live cells. PNAS $2002993294-3299$.

66 Rocheville M, Lange D, Kumar U, Patel S, Patel R \& Patel Y. Receptors for dopamine and somatostatin: formation of heterooligomers with enhanced functional activity. Science $2000 \mathbf{2 8 8}$ $154-157$

67 Rocheville M, Lange D, Kumar U, Sasi R, Patel R \& Patel Y. Subtypes of the somatostatin receptor assemble as functional homoand heterodimers. Journal of Biological Chemistry $2000 \mathbf{2 7 5}$ $7862-7869$.

68 Patel R, Lange D \& Patel Y. Photobleaching fluorescence resonance energy transfer reveals ligand-induced oligomer formation of human somatostatin receptor subtypes. Methods 200227 $340-348$.

69 Pfeiffer M, Koch T, Schroder H, Laugsch M, Hollt V \& Schulz S. Heterodimerization of somatostatin and opioid receptors crossmodulates phosphorylation, internalization and desensitization. Journal of Biological Chemistry 2002277 19762-19772.

70 Saveanu A, Gunz G, Dufour H, Caron P, Fina F, Ouafik L, Culler M, Moreau J, Enjalbert A \& Jaquet P. BIM 23244, a somatostatin receptor subtype 2 and 5 selective analog with enhanced efficacy in suppressing growth hormone $(\mathrm{GH})$ from octreotide-resistant human GH-secreting adenomas. Journal of Clinical Endocrinology and Metabolism 2001 86 140-145.

71 Saveanu A, Lavaque E, Gunz G, Barlier A, Kim S, Taylor J, Culler M, Enjalbert A \& Jaquet P. Demonstration of enhanced 
potency of a chimeric somatostatin-dopamine molecule, BIM23A387, in suppressing growth hormone and prolactin secretion from human pituitary somatotroph adenoma cells. Journal of Clinical Endocrinology and Metabolism $2002 \mathbf{8 7}$ 5545-5552.

72 Baragli A, Kumar U, Patel R \& Patel Y. Hetero-oligomerisation of dopamine (D2R) and somatostatin receptors (sstr2) in CHO-K1 cells and cortical cultured neurons. Proceeding of Endocrine Society, Philadelphia 2003469 (Abstract).

73 Ferone D, Pivonello R, Van Hagen M, Dalm V, LichtenauerKaligis E, Waaijers M, Van Koetsveld P, Mooy D, Colao A, Minuto F, Lamberts S \& Hofland L. Quantitative and functional expression of somatostatin receptor subtypes in human thymocytes. American Journal of Physiology, Endocrinology and Metabolism 2002283 E1056-E1066.

74 Shimon I, Taylor J, Dong J, Bitonte R, Kim S, Morgan B, Coy D, Culler M \& Melmed S. Somatostatin receptor subtype specificity in human fetal pituitary cultures. Differential role of SSTR2 and SSTR 5 for growth hormone, thyroid-stimulating hormone and prolactin regulation. Journal of Clinical Investigation 199799 $789-798$.

75 Jaquet P, Ouafik L, Saveanu A, Gunz G, Fina F, Dufour H, Culler M, Moreau J \& Enjalbert A. Quantitative and functional expression of somatostatin receptor subtypes in human prolactinomas. Journal of Clinical Endocrinology and Metabolism 199984 3268-3276.

76 Rohrer SP, Birzin ET, Mosley RT, Scott CB, Hutchins SM, Shen DM, Xiong Y, Hayes EC, Parmar RM, Foor F, Mitra SW, Degrado SJ, Shu M, Klopp JM, Cai SJ, Blake A, Chan WWS, Pasternak A, Yang L, Patchett AA, Smith RG, Chapman KT \& Schaeffer JM. Rapid identification of subtype-selective agonists of the somatostatin receptor through combinatorial chemistry. Science 1998 $282737-740$.

77 Held-Feindt J, Forstreuter F, Pufe T \& Mentlein R. Influence of the somatostatin receptor sst 2 on growth factor signal cascades in human glioma cells. Brain Research and Molecular Brain Research $20018712-21$

78 Yang L, Berk S, Rohrer S, Mosley RT, Guo L, Underwood D, Arison B, Birzin E, Hayes E, Mitra S, Parmar R, Cheng K, Wu T, Butler B, Foor F, Pasternak A, Pan Y, Silva M, Freidinger R, Smith R, Chapman K, Schaeffer J \& Pattchett A. Synthesis and biological activities of potent peptidomimetics selective for somatostatin receptor subtype 2. PNAS $1998 \quad \mathbf{9 5}$ 10836-10841.

79 Poitout L, Roubert P, Contour-Galcera M, Moinet C, Lannoy J, Pommier P, Plas P, Bigg D \& Thurieau C. Identification of potent non-peptide somatostatin antagonist with sst3 selectivity. Journal of Medical Chemistry 2001 44 2990-3000.

80 Liu S, Tang C, Ho B, Ankersen M, Stidsen C \& Crider A. Nonpeptide somatostatin agonists with sst4 selectivity: synthesis and structure-activity relationship of thioureas. Journal of Medical Chemistry 199841 4693-4705.

81 Hadcock J, Strnad J \& Eppler C. Rat somatostatin receptor type 1 couples to G proteins and inhibition of cyclic AMP accumulation. Molecular Pharmacology 199445 410-416.

82 Kubota A, Yamada Y, Kagimoto S, Yasuda K, Someya Y, Ihara Y, Okamoto Y, Kozasa T \& Seino S. Multiple effector coupling of somatostatin receptor subtype SSTR1. Biochemical and Biophysical Research Communications 1994204 176-186.

83 Strnad J, Eppler C, Corbett M \& Hadcock J. The rat SSTR2 somatostatin receptor subtype is coupled to inhibition of cyclic AMP accumulation. Biochemical and Biophysical Research Communications $1993191968-976$.

84 Kagimoto S, Yamada Y, Kubota A, Someya Y, Ihara Y, Yasuda K, Kozasa T, Imura H, Seino S \& Seino Y. Human somatostatin receptor SSTR2 is coupled to adenylyl cyclase in the presence of Gi alpha 1 protein. Biochemical and Biophysical Research Communications 1994202 1188-1195.

85 Yamada Y, Reisine T, Law SF, Ihara Y, Kubota A, Kagimoto S, Seino M, Seino Y, Bell GI \& Seino S. Somatostatin receptors, an expanding gene family: cloning and functional characterization of human SSTR3, a protein coupled to adenylyl cyclase. Molecular Endocrinology $199262136-2142$.

86 Yasuda K, Rens-Domiano S, Breder CD, Law SF, Saper CB, Reisine T \& Bell GI. Cloning of a novel somatostatin receptor, SSTR3, coupled to adenylyl cyclase. Journal of Biological Chemistry $1992 \mathbf{2 6 7} 20422-20428$.

87 Siehler S \& Hoyer D. Characterization of human recombinant somatostatin receptor 3. Modulation of adenylate cyclase activity. Naunyn Schmiedeberg's Archives of Pharmacology 1999 $360510-521$.

88 Bito H, Mori M, Sakanaka C, Takano T, Honda Z, Gotoh Y, Nishida E \& Shimizu T. Functional coupling of SSTR4, a major hippocampal somatostatin receptor, to adenylate cyclase inhibition, arachidonate release, and activation of the mitogenactivated protein kinase cascade. Journal of Biological Chemistry $199426912722-12730$.

89 Kaupmann K, Bruns C, Hoyer D, Seuwen K \& Lübbert H. Distribution and second messenger coupling of four somatostatin receptor subtypes expressed in brain. FEBS Letters 1993331 53-59.

90 Panetta R, Greenwood M, Warszynska A, Demchyshyn L, Day R, Niznik H, Srikant C \& Patel Y. Molecular cloning, functional characterization, and chromosomal localization of a human somatostatin receptor (somatostatin receptor type 5) with preferential affinity for somatostatin-28. Molecular Pharmacology 1994 $45417-427$.

91 Raynor K, O'Carrol A, Kong H, Yasuda K, Mahan L, Bell G \& Reisine T. Characterization of cloned somatostatin receptors SSTR4 and SSTR5. Molecular Pharmacology 199344 385-392.

92 Roosterman D, Glassmeier G, Baumeister H, Scherubl H \& Meyerhof W. A somatostatin receptor 1 selective ligand inhibits $\mathrm{Ca}^{2+}$ currents in rat insulinoma 104638 cells. FEBS Letters $1998425137-140$.

93 Fujii Y, Gonoi T, Yamada Y, Chihara K, Inagaki N \& Seino S. Somatostatin receptor subtype 2 SSTR2 mediates the inhibition of high-voltage-activated calcium channels by somatostatin and its analogue SMS 201-995. FEBS Letters 1994355 117-120.

94 Degtiar V, Wittig B, Schultz G \& Kalkbrenner F. A specific G(o) heterotrimer couples somatostatin receptors to voltage-gated calcium channels in RINm5F cells. FEBS Letters $1996 \mathbf{3 8 0}$ 137-141.

95 Tallent M, Liapakis G, O'Carrol A, Lolait S, Dichter M \& Reisine T. Somatostatin receptor subtypes SSTR 2 and SSTR 5 couple negatively to an L-type $\mathrm{Ca}^{2+}$ current in the pituitary cell line AtT-20. Neuroscience 199671 1073-1081.

96 Taylor J. Somatostatin (SSTR2) receptors mediate phospholipase $\mathrm{C}$-independent $\mathrm{Ca}^{2+}$ mobilization in rat AR42J pancreas cells. Biochemical and Biophysical Research Communications 1995214 $81-85$.

97 Karschin A. Molecular single-cell analysis identifies somatostatin type 1 (sst1) receptors to block inwardly rectifying $\mathrm{K}+$ channels in rat brain oligodendrocytes. Neuroreport 19957 121-124.

98 Kreienkamp H, Honck H \& Richter D. Coupling of rat somatostatin receptor subtypes to a G-protein gated inwardly rectifying potassium channel (GIRK1). FEBS Letters $199741992-94$.

99 Akbar M, Okajima F, Tomura H, Majid MA, Yamada Y, Sino S \& Kondo Y. Phospholipase $\mathrm{C}$ activation and $\mathrm{Ca}^{2+}$ mobilization by cloned human somatostatin receptor subtypes 1-5 in transfected COS-7 cells. FEBS Letters 1994348 192-196.

100 Chen L, Fitzpatrick V, Vandlen R \& Tashijan JA. Both overlapping and distinct signaling pathways for somatostatin receptor subtypes SSTR1 and SSTR2 in pituitary cells. Journal of Biological Chemistry $199727218666-18672$.

101 Tomura H, Okajima F, Akbar M, Abdul M, Sho K \& Kondo Y. Transfected human somatostatin receptor type 2, SSTR2, not only inhibits adenylate cyclase but also stimulates phospholipase $\mathrm{C}$ and $\mathrm{Ca}^{2+}$ mobilization. Biochemical and Biophysical Research Communications 1994200 986-992. 
102 Murthy K, Coy D \& Makhlouf G. Somatostatin receptor-mediated signaling in smooth muscle. Activation of phospholipase-C beta3 by Gbeta/gamma and inhibition of adenylyl cyclase by Galphai and Galpha0. Journal of Biological Chemistry 1996 $27123458-23463$.

103 Siehler S \& Hoyer D. Characterization of human recombinant somatostatin receptor 4 . Modulation of phospholipase $C$ activity. Naunyn Schmiedeberg's Archives of Pharmacology $19993 \mathbf{3 6 0}$ $522-532$.

104 Florio T, Yao H, Carey K, Dillon T \& Stork P. Somatostatin activation of mitogen-activated protein kinase via somatostatin receptor 1 (SSTR1). Molecular Endocrinology 199913 24-37.

105 Cattaneo M, Amoroso D, Gussoni G, Sanguini A \& Vicentini L. A somatostatin analog inhibits MAP kinase activation and cell proliferation in human neuroblastoma and human small cell lung carcinoma cell lines. FEBS Letters 1996397 164-168.

106 Yoshitomi H, Fujii Y, Miyazaki M, Nakajima N, Inagaki N \& Seino S. Involvmement of MAP kinase and c-fos signaling in the inhibition of cell growth by somatostatin. American Journal of Physiology 1997272 E769-E774.

107 Sellers L. Prolonged activation of extracellular signal-regulated kinase by a protein kinase C-dependent and N17Ras-insensitive mechanism mediates the proliferative response of $\mathrm{G}(\mathrm{i} / \mathrm{o})$-coupled somatostatin sst(4) receptors. Journal of Biological Chemistry $199927424280-24288$.

108 Florio T, Rim C, Hershberger RE, Loda M \& Stork PJS. The somatostatin receptor SSTR1 is coupled to phosphotyrosine phosphatase activity in CHO-K1 cells. Molecular Endocrinology 19948 1289-1297.

109 Lopez F, Esteve JP, Buscail L, Delesque N, Saint-Laurent N, Theveniau M, Nahmias C, Vaysse N \& Susini C. The tyrosine phosphatase SHP-1 associates with the sst 2 somatostatin receptor and is an essential component of sst2-mediated inhibitory growth signaling. Journal of Biological Chemistry $19972 \mathbf{2 7 2}$ 24448-24454.

110 Reardon D, Dent P, Wood S, Kong T \& Sturgill T. Activation in vitro of somatostatin receptor subtypes 2,3 or 4 stimulates protein tyrosine phosphatase activity in membranes from transfected Ras-transformed NIH 3T3 cells: coexpression with catalytically inactive SHP-2 blocks responsivness. Molecular Endocrinology 199711 1062-1069.

111 Sharma K, Patel Y \& Srikant C. C-terminal region of human somatostatin receptor 5 is required for induction of $\mathrm{Rb}$ and G1 cell cycle arrest. Molecular Endocrinology 199913 82-90.
112 Hou C, Gilbert R \& Barber D. Subtype-specific signaling mechanisms of somatostatin receptors SSTR1 and SSTR2. Journal of Biological Chemistry $199426910357-10362$.

113 Chen L \& Tashijan JAH. Identification of distinct signaling pathways for somatostatin receptors SSTR1 and SSTR2 as revealed by microphysiometry. Cell Signaling 199911 499-505.

114 Smalley K, Feniuk W \& Humphrey P. Differential agonist activity of somatostatin and L-362855 in human recombinant sst4 receptors. British Journal of Pharmacology $1995125833-841$.

115 Thoss V, Perez J, Probst A \& Hoyer D. Expression of five somatostatin receptor mRNAs in the human brain and pituitary. Naunyn Schmiedeberg's Archives of Pharmacology $1996 \mathbf{3 5 4}$ 411-419.

116 Rohrer L, Raulf F, Bruns C, Buettner R, Hofstaedter F \& Schüle R. Cloning and characterization of a fourth human somatostatin receptor. PNAS 199390 4196-4200.

117 Raulf F, Pérez J, Hoyer D \& Bruns C. Differential expression of five somatostatin receptor subtypes, sstr1-5, in the CNS and peripheral tissue. Digestion $1994 \mathbf{5 5}$ 46-53.

118 O'Carrol AM, Raynor K, Lolait SJ \& Reisine T. Characterization of cloned human somatostatin receptor SSTR5. Molecular Pharmacology $199446291-298$.

119 Le Romancer M, Cherifi Y, Levasseur S, Laigneau J, Peranzi G, Jais P, Lewin M \& Reyl-Desmars F. Messenger RNA expression of somatostatin receptor subtypes in human and rat gastric mucosae. Life Sciences $1996 \mathbf{5 8} 1091-1098$.

120 Yamada Y, Post S, Wang K, Tager H, Bell G \& Seino S. Cloning and functional characterization of a family of human and mouse somatostatin receptors expressed in brain, gastrointestinal tract and kidney. PNAS $199289251-255$.

121 Zaki M, Harrington L, McCuen R, Coy D, Arimura A \& Schubert M. Somatostatin receptor subtype 2 mediates inhibition of gastrin and histamine secretion from human, dog and rat antrum. Gastroenterology $1996111919-924$.

122 Reubi J, Horisberger U, Studer U, Waser B \& Laissue J. Human kidney as target for somatostatin: high affinity receptors in tubules and vasa recta. Journal of Clinical Endocrinology and Metabolism 199377 1323-1328.

Received 6 July 2004

Accepted 28 September 2004 